\title{
Rhizoclonium grande Bioethanol in Biofuel Production by Transesterification of Jatropha curcas Oil
}

\author{
J. Mwangi Kahindo ${ }^{*}$, Sumesh C. Chhabra ${ }^{2}$, Richard Musau ${ }^{2}$, Odalo J. Ochieng ${ }^{1}$, Thomas Thoruwa ${ }^{3}$ \\ ${ }^{1}$ Department of Pure and Applied Science, Technical University of Mombasa (TUM), Mombasa, Kenya \\ ${ }^{2}$ Chemistry Department, Kenyatta University, Nairobi, Kenya \\ ${ }^{3}$ Department of Physics and Technology, Pwani University, Kilifi, Kenya \\ Email: *kahinjm@gmail.com
}

How to cite this paper: Kahindo, J.M., Chhabra, S.C., Musau, R., Ochieng, O.J. and Thoruwa, T. (2018) Rhizoclonium grande Bioethanol in Biofuel Production by Transesterification of Jatropha curcas Oil. Green and Sustainable Chemistry, 8, 62-73. https://doi.org/10.4236/gsc.2018.81005

Received: November 15, 2017

Accepted: February 4, 2018

Published: February 7, 2018

Copyright $\odot 2018$ by authors and Scientific Research Publishing Inc. This work is licensed under the Creative Commons Attribution International License (CC BY 4.0).

http://creativecommons.org/licenses/by/4.0/

\begin{abstract}
There is a need for an alternative sustainable fuel based on renewable sources and efficient carbon dioxide scrubbers. Alkyl esters prepared by transesterification of vegetable oils from various plants have been evaluated. In this work the potential of sustainable macroalgae bioethanol in biofuel production by transesterification of Jatropha curcas oil was assessed. Rhizoclonium grande macroalgae was collected from Shimoni shores in Kwale, Shelly beach in Mombasa, Jamvi la Wageni in Mtongwe Likoni, English point near Kenya Marine and Fisheries Research Institute (KMFRI) Mombasa, dried and processed to obtain $5.36 \% \pm 0.355 \% \mathrm{v} / \mathrm{w}$ bioethanol using Aspergilus niger for hydrolysis and Saccharomyces cerevisiae for fermentation. J. curcas seeds were collected from contracted farmers of Energy Africa in Shimba hills, Coast region. Oil from the seeds was machine cold pressed and solvent extracted using $\mathrm{n}$-hexane giving $44 \%-53 \% \mathrm{v} / \mathrm{w}$ yield. The physicochemical properties of the J. curcas oil were investigated. Transesterification of J. curcas oil was carried out using bioethanol from the algae with 63\% - 70\% FAEE yield. Characterisation of the bioethanol and ethyl esters was done using GCMS. Physicochemical and fuel properties of the biofuel were investigated at Technical University of Mombasa (TUM), Jomo Kenyatta University of Agriculture and Technology (JKUAT), Government Chemist and Kenya Pipeline Laboratories in Mombasa. There was significant difference in physicochemical and fuel properties observed in density, calorific value, kinematic viscosity, pour point and cloud point between the Jatropha oil and Jatropha fatty acid ethyl esters (JAT FAEE) samples. No significant difference observed in the physicochemical and fuel properties between the JAT FAEE and standard biodiesel samples. This was according to statistical analysis of data done
\end{abstract}


using STATA/SE 13.0 and Xlstat at 95\% confidence level $(\mathrm{P}<0.05)$ twotailed. From the findings bioethanol from $R$. grande biomass used in transesterification has a potential to improve the sustainability, physicochemical and fuel properties of biofuel from J. curcas a non-food crop. The effect of the use of bioethanol and its byproduct on shelf life of the biofuel can further be investigated.

\section{Keywords}

Jatropha curcas, Rhizoclonium grande, Biofuel, Physico-Chemical Properties and Fuel Properties

\section{Introduction}

There is a need for non-food crops biomass such as J. curcas L. (Plate 1(a) and Plate 1(b)) and carbon dioxide scrubbers such as algae for alcohol biomass source in biofuel production. Algae can produce up to 30 times more energy per acre than land crops such as soyabean hence more sustainable [1]. J. curcas seeds husked (Plate 2(a)) and dehusked (Plate 2(b)) constitute 53\% - 57\% non-edible oils [2] [3].

Lower alcohols such as methanol, ethanol, and butanol are the most frequently employed in transesterification of plant based oils [4] [5] [6]. The preference of the alcohol is based on cost and performance. Ethanol may be preferable to methanol because of its dissolving power for oils and less toxicity. Ethanol when

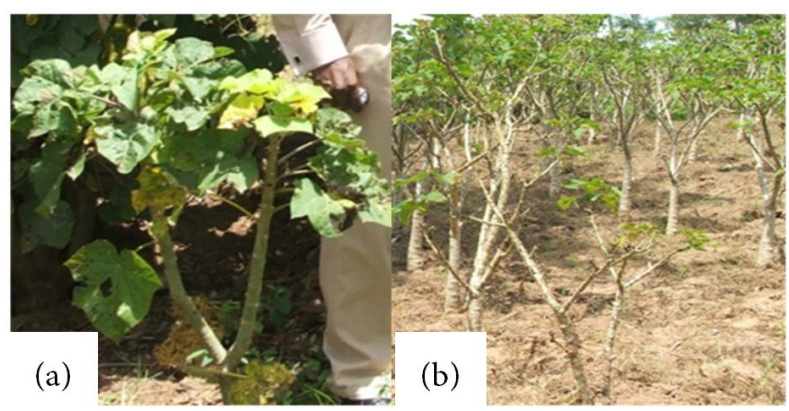

Plate 1. J. curcas crop (a) young; (b) mature.

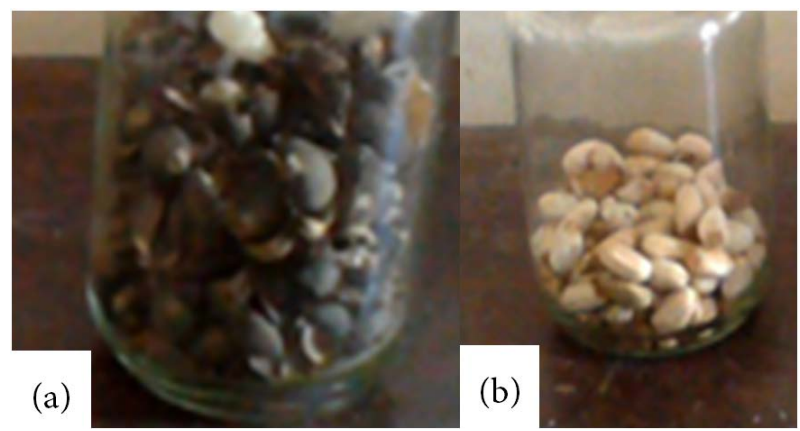

Plate 2. J. curcas seeds (a) husked; (b) dehusked. 
used for the transesterification of vegetables oils produces ethyl esters rather than methyl esters. The extra carbon atom provided by the ethanol molecule slightly increases the heat content and the cetane number of the biodiesel [7].

Potassium and sodium hydroxide are the most commonly used homogenous alkali catalysts in the transesterification of oil with very low free fatty acid content. Alkali metal catalysts are found to be more effective than acidic catalyst [8].

A biofuel from Jatropha curcas oil and bioethanol from algae biomass would improve sustainability since algae can be easily cultured and easily produced. There is scanty information on renewable sources of ethanol for transesterification apart from edible sources of carbohydrates and lignocelluloses that may require complex pretreatment to remove lignin. Biodiesel have advantages such as increased lubricity and reduction of exhaust emissions than petroleum based diesel [9].

This work sought to assess physicochemical and fuel properties of fatty acid ethyl esters obtained from transesterification of Jatropha curcas L. oil using bioethanol from algae Rhizoclonium grande. The performance of the biofuel was compared with standard biodiesel. This work was an attempt to unveil a more sustainable, cheap and quality biofuel.

\section{Materials and Methods}

\subsection{Sample Collection and Pretreatment}

J. curcas seeds were collected from Shimba hills, Kwale County which one of the major Jatropha growing area. The farmers contracted by the out grower scheme Energy Africa were randomly sampled by snow balling and the seeds were bought in 50 kilogram gunny polypropene bags. The husked seeds were transported to Technical University of Mombasa (TUM) where they were dehusked using a locally fabricated dehusker. The dehusked seeds were weighed and preserved in polythene bags in an air conditioned room at temperature $25^{\circ} \mathrm{C}$ ready for extraction.

Macroscopic and filamentous marine algae species $R$. grande was randomly collected from different sampling sites namely Shimoni shores in Kwale County South Coast, Shelly beach in Likoni South Coast, Jamvi la Wageni in Likoni South Coast, English point near Kenya Marine and Fisheries Research Institute (KMFRI) Mombasa North coast and Tudor Creek near Kenya Meat Commission along Makupa Causeway. The macroalgae and filamentous species, identified by a taxonomist from KMFRI as R. grande, was collected and put in $5 \mathrm{~kg}$ polythene sample bags. The samples were kept in cold boxes and transported to Technical University Laboratories for further treatment. The algae biomass was dried under a shade for three days then it was ground to powder using Hamilton Beach commercial blender.

The algal biomass was extracted with hexane to remove the oil component. The extracted material was collected and dried at $80^{\circ} \mathrm{C}$ to remove trapped hexane. The dried $R$. grande biomass were sieved through sieve of mesh number 18 
equivalent to $1 \mathrm{~mm}$ pore. The fine powder obtained was used for saccharification and fermentation experiments.

\subsection{Saccharification of the Algal Biomass}

The de-oiled [10] and dried fine powder (150 g) of marine algae $R$. grande were weighed and formed the biomass for ethanol production. The fungi Aspergillus niger for saccharification was obtained from Microbiology Laboratory Kenyatta University. The fungi was cultured and maintained on potato dextrose agar medium at $30^{\circ} \mathrm{C}$.

Mycelial mat of $A$. niger was weighed $(0.85 \mathrm{~g})$ on analytical balance and added to the biomass, $75 \mathrm{ml}$ of distilled water was added and homogenised using a sterile blender and then transferred into stainless steel trays. The biomass was allowed to start decaying to rapture the thin cell walls and release fermentable carbohydrates by $A$. niger. The saccharification was carried out for a period of six days at $30^{\circ} \mathrm{C}$.

\subsection{Spectrophotometric Analysis of Reducing Sugars Produced During Saccharification}

The reducing sugar level was followed by use of UV-Visible spectrophotometry Miller's Dinitrosalicylic method [11]. The process was monitored every $24 \mathrm{hrs}$ for sugars released by Millers method of glucose estimation using standard calibration graph. $100 \mathrm{mg}$ of glucose in $100 \mathrm{ml}$ of distilled water was prepared as the reducing sugar standard stock solution. $0.2,0.4,0.6,0.8$ and $1 \mathrm{ml}$ from the stock solution in $10 \mathrm{ml}$ of solution in distilled water were further prepared and used as the standard solutions for calibration. Similarly sample solutions were prepared by $2 \mathrm{~g}$ of sample biomass in $100 \mathrm{ml}$ distilled water followed by filtration.

\subsection{Fermentation of Saccharised Algal Biomass}

The fungi Saccharomyces cerevisiae for fermentation was obtained from Agrochemical and Food Company Limited. The yeast Saccharomyces cerevisiae was cultured and maintained on yeast extract, peptone and dextrose (YPD) agar media at $30^{\circ} \mathrm{C}$. After 6 days $10 \%$ of the brewers' yeast was added to the fermentable solution. The mixture was allowed to ferment for 4 days at room temperature $30^{\circ} \mathrm{C}$

\subsection{Separation of Algal Bioethanol by Fractional Distillation}

The bioethanol produced was then separated from the fermentation solution by fractional distillation method [12]. Ethanol boils at $78.4^{\circ} \mathrm{C}$ while water boils at $100{ }^{\circ} \mathrm{C}$. When the mixture was heated, ethanol which is the most volatile component concentrated to a greater degree in the vapor phase and left the liquid. The distillate formed an azeotrope, comprising of mainly $96 \%$ bioethanol and $4 \%$ water at $78.2^{\circ} \mathrm{C}$ and the mixture is more volatile than pure ethanol. For this reason, ethanol was further purified by dehydration using anhydrous magne- 
sium sulphate [13].

\subsection{Extraction and Analysis of Oil from Jatropha curcas Dehusked Seeds}

J. curcas oil (JO) was extracted from dehusked seeds using fabricated cold oil press and n-hexane as the solvent and also industrial blender for grinding. The oil was allowed to settle then filtered using vacuum filtration. For the solvent extracted oil from the cake the solvent was recovered by vacuum evaporator model ROVA-3L at $50^{\circ} \mathrm{C}$ with a negative pressure $450 \mathrm{mmHg}$ and reused. The amount of oil was measured using a $100 \mathrm{ml}$ measuring cylinder and kept in a refrigerator at $4^{\circ} \mathrm{C}$ and later analysed for oil physicochemical properties using ASTM procedures and Association of Official Analytical Chemists (AOAC), official methods [14].

\subsection{Transesterification of Jatropha Curcas Oil and Analysis}

Dry bioethanol prepared from marine algae $R$. grande L. biomass was used for transesterification [15]. Dry potassium hydroxide was reacted with the bioethanol to produce the ethoxide ions mixture in a ratio of $1: 10$. The mixture was added to J. curcas L. oil in a ratio of 3:10 ethoxide ion solution from the bioethanol to oil preheated at $65^{\circ} \mathrm{C}$ with constant stirring using a mechanical stirrer at $200 \mathrm{rpm}$ for two hours to produce fatty acid ethyl ester biofuels [16] [17]. The ethyl esters were then separated from the glycerol by centrifugation using centrifuge Model Neofuge 15R at 10,000 rpm for 15 minutes followed by decantation, washing with distilled water and drying. Any bioethanol residues blends with the biodiesel [18]. The ethyl esters from J. curcas L oil were analysed by GC-MS analysis [19] to ascertain composition. The crude fatty acid ethyl esters (FAEE) were then analysed for physicochemical and fuel properties using ASTM D6751 standard test methods which were compared with those of standard biodiesel.

\subsection{Data Analysis}

Three independent replicates were used per analysis and the results were expressed as mean values \pm standard deviation of mean. Analysis of variance (ANOVA) followed by Post-Hoc test $(\mathrm{P} \leq 0.05)$ was used for comparison and separation of mean. Exploratory data analysis and standard statistical analyses were done using the statistical software package STATA, version SE 13 (STATA/ SE13 ๑ 1985-2013 StataCorp LP.

\section{Results and Discussion}

\subsection{Fermentable Sugars from Algae Biomass}

After 6 days the amount of reducing sugar present in $100 \mathrm{~g}$ algae biomass was $47.82 \mathrm{~g}$. Generally the conversion level for Rhizoclonium grande algae biomass of $19.01 \%$ (Table 1) is similar to that reported for spirogyra biomass a similar fi- 
lamented green algae. The amount of carbohydrates in some algae can be $40 \%$ $60 \%$ [20]. This is sufficient for fermentation.

\subsection{Bioethanol Yield from $R$ grande}

Shelly beach algae recorded the highest bioethanol production 5.83\% and Jamvi la Wazee the lowest 5.00\%. Devedra and Rackesh, 2013 recorded $6 \mathrm{~g} / 100 \mathrm{~g}$ biomass from algal biomass. The difference in conversion rate in $R$. algae may be due to the greater toughness of the cell wall that makes it harder for the fungi to rupture. On average $R$. grande produced $5.36 \% \pm 0.355 \% \mathrm{v} / \mathrm{w}$ of bioethanol (Table 2).

\subsection{GC-MS Spectra of Bioethanol}

GC-MS spectra of bioethanol from $R$. grande biomass after fractional distillation and drying using anhydrous magnesium sulphate showed the main component is ethanol $\mathrm{Rt}=1.965$ with some small quantities of methanol $\mathrm{Rt}=1.852$. Main $\mathrm{m} / \mathrm{z}$ values of ethanol are 18.1, 31 and 45 and methanol m/z 18.1 and 31 .

\subsection{Jatropha curcas Oil from Dehusked Seeds}

The \% mean mass of $J$. curcas dehusked seeds from different contracted farmers in an out grower scheme Energy Africa in Shimba hills, Kwale County ranged from $58.679 \%$ to $64.544 \%$. This can be attributed to difference in soil texture, nutrients and $\mathrm{pH}$. The volume of Jatropha oil extracted from $J$. curcas using

Table 1. Reducing sugars produced during saccharification of algae biomass.

\begin{tabular}{ccccc}
\hline Day & $\begin{array}{c}\text { Absorbance of } \\
2.5 \mathrm{~g} / \mathrm{l} \text { biomass }\end{array}$ & $\begin{array}{c}\text { Concentration of } \\
\text { reducing sugars (mg/l) } \\
\text { from } 2.5 \mathrm{~g} / \mathrm{l} \text { biomass }\end{array}$ & $\begin{array}{c}\text { Amount of reducing } \\
\text { sugars per } 100 \text { gram } \\
\text { biomass }\end{array}$ & $\begin{array}{c}\text { \% conversion to } \\
\text { reducing sugars }\end{array}$ \\
\hline 0 & 0.284 & $720.25 \pm 0.19$ & 28.81 & - \\
1 & 0.402 & $1174.54 \pm 0.28$ & 46.96 & 18.17 \\
2 & 0.403 & $1176.23 \pm 0.22$ & 47.04 & 18.31 \\
3 & 0.406 & $1178.04 \pm 0.21$ & 47.12 & 18.33 \\
4 & 0.406 & $1178.38 \pm 0.29$ & 47.13 & 18.99 \\
5 & 0.409 & $1195.03 \pm 0.19$ & 47.80 & 19.01 \\
\hline
\end{tabular}

Table 2. Amount of bioethanol produced after fermentation of algae biomass.

\begin{tabular}{cccc}
\hline Sample & Biomass $(\mathrm{g})$ & Bioethanol $(\mathrm{ml})$ & \% v/w yield of bioethanol \\
\hline Algae-Jamvi & 150 & 7.50 & 5.00 \\
Algae-Tudor & 150 & 8.10 & 5.40 \\
Algae-Shelly & 150 & 8.75 & 5.83 \\
Algae-Shimoni & 150 & 7.80 & 5.20 \\
Mean \pm SD & & $8.04 \pm 0.534$ & $5.36 \pm 0.355$ \\
\hline
\end{tabular}


hexane after cold pressing or grinding by blender from five sampling fields in Shimba Hills. The amount of Jatropha curcas oil obtained by cold press followed by hexane extraction was lower $330 \pm 1.00 \mathrm{ml}(44 \% \pm 0.130 \%)$ than that obtained by blender followed by hexane extraction (51\% - 53\%) (Table 3). This may be attributed to loss during pressing by evaporation and wetting of the cold press. Jatropha curcas kernels have about $50 \%$ oil [21]. The oil recovery in mechanical expeller is about $85 \%$, while more than $95 \%$ recovery of oil could be achieved when extracted by solvent method. The mean yields using blender and hexane solvent were similar to those reported $40 \%$ - 60\% [22] [23] [24].

\subsection{Physicochemical Properties of Jatropha curcas Oil}

The oils extracted from Jatropha curcas was analysed [25] for physicochemical and thermodynamic properties using AOCS, AOAC and ASTM standard test methods which include: Density $\mathrm{kg} / \mathrm{dm}^{3}$ ASTM D1298 at $20^{\circ} \mathrm{C}$, Kinematic Viscosity at $40^{\circ} \mathrm{C}$ (cSt) ASTM D445, Refractive index (AOAC Method 920.212), Acid value (ISO Method 660:2009), Iodine value (AOAC Method 920.159) and Saponification value (AOAC Method 920.160). The results were recorded (Table 4). The density and kinematic viscosity of the Jatropha curcas oil (JO) is more than the standard biodiesel. The high density, refractive index and kinematic viscosity may be due to the difference in molecular weight of fatty acids in the oil. The high kinematic viscosity confirms that the oil require transesterification to reduce the viscosity. It also indicates the relative difficulty of pumping the oil. The flash point is higher than for petroleum based diesel (Table 4). From the flash point values it implies that the oil (JO) has no storage or handling problem without serious fire hazards. The heating value and cetane number are almost similar to petroleum diesel. These properties are mainly dependent on the elements present in the oils namely carbon, hydrogen and oxygen. Iodine value is more in Jatropha oil but lower than 120 hence can readily be used as biofuel feedstock. The use of iodine value of a maximum of 120 can serve to restrict certain vegetable oils as biodiesel feedstocks especially when oxidative stability specification parameter are not included in the analysis [26].

Table 3. \% yield of Jatropha oil per gram of biomass from each sampling site.

\begin{tabular}{cccc}
\hline Sampling field & $\begin{array}{c}\text { Jatropha biomass } \\
(\mathrm{g})\end{array}$ & $\begin{array}{c}\text { Jatropha oil produced } \\
(\mathrm{ml})(\mathrm{mean} \pm \mathrm{SD})\end{array}$ & $\begin{array}{c}\text { \%v/w yield of Jatropha oil per } \\
\text { gram biomass (mean } \pm \text { SD) }\end{array}$ \\
\hline JOFA $^{\mathrm{a}}$ & 750 & $330 \pm 1.00$ & $44 \pm 0.130$ \\
JOFA $^{\mathrm{b}}$ & 750 & $390 \pm 2.00$ & $52 \pm 0.267$ \\
JOFB $^{\mathrm{b}}$ & 750 & $400 \pm 1.00$ & $53 \pm 0.135$ \\
JOFC $^{\mathrm{b}}$ & 750 & $380 \pm 2.00$ & $51 \pm 0.267$ \\
JOFD $^{\mathrm{b}}$ & 750 & $390 \pm 5.00$ & $52 \pm 0.667$ \\
JOFE $^{\mathrm{b}}$ & 750 & $385 \pm 4.36$ & $51 \pm 0.581$ \\
\hline
\end{tabular}

${ }^{\text {a }}$ Sample obtained by cold press followed by hexane; ' Sample obtained by blender followed by hexane. 
Table 4. Physicochemical properties of jatropha oil.

\begin{tabular}{|c|c|c|c|c|c|c|}
\hline \multirow[b]{2}{*}{$\begin{array}{l}\text { Jatropha } \\
\text { oil } \\
\text { Sample }\end{array}$} & \multicolumn{6}{|c|}{ Physicochemical oil Properties (mean \pm SD) } \\
\hline & $\begin{array}{l}\text { Density } \mathrm{kg} / \mathrm{m}^{3} \\
\text { ASTM } \\
\text { D1298 at } 20^{\circ} \mathrm{C}\end{array}$ & $\begin{array}{c}\text { Refractive index } \\
\text { (AOAC Method 920.212) }\end{array}$ & $\begin{array}{c}\text { Kinematic } \\
\text { Viscosity at } 40^{\circ} \mathrm{C} \\
\text { (cSt) ASTM D445 }\end{array}$ & $\begin{array}{l}\text { Acid Value mg KOH/g } \\
\text { (ISO Method 660:1996) }\end{array}$ & $\begin{array}{c}\text { Iodine Value } \mathrm{mg} / \mathrm{g} \\
\text { (AOAC Method 920.159) }\end{array}$ & $\begin{array}{l}\text { Saponification Value } \mathrm{mg} / \mathrm{g} \\
\text { (AOAC Method 920.160) }\end{array}$ \\
\hline JOFA $^{\mathrm{b}}$ & $917 \pm 1.12$ & $1.497 \pm 0.012$ & $34.12 \pm 0.16$ & $36.58 \pm 0.12$ & $106 \pm 1.0$ & $194.5 \pm 0.1$ \\
\hline $\mathrm{JOFB}^{\mathrm{b}}$ & $916 \pm 1.03$ & $1.496 \pm 0.010$ & $33.96 \pm 0.13$ & $36.57 \pm 0.16$ & $106 \pm 1.0$ & $195.2 \pm 0.3$ \\
\hline $\mathrm{JOFC}^{\mathrm{b}}$ & $916 \pm 0.19$ & $1.496 \pm 0.011$ & $34.10 \pm 0.09$ & $36.40 \pm 0.13$ & $107 \pm 0.0$ & $195.6 \pm 0.6$ \\
\hline $\mathrm{JOFD}^{\mathrm{b}}$ & $916 \pm 1.10$ & $1.496 \pm 0.012$ & $34.09 \pm 0.12$ & $36.46 \pm 0.18$ & $108 \pm 0.0$ & $195.8 \pm 0.2$ \\
\hline JOFE $^{\mathrm{b}}$ & $916 \pm 1.02$ & $1.496 \pm 0.015$ & $35.20 \pm 0.11$ & $36.49 \pm 0.15$ & $106 \pm 1.0$ & $194.9 \pm 0.1$ \\
\hline
\end{tabular}

\subsection{Ethyl Esters Yield from Jatropha curcas Oil}

The percentage yield of the ethyl esters was highest in oil from JOFC (70\%) and the least was that from JOFE (63\%) (Table 5). The values are lower than those in literature [27] for Jatropha oil methyl esters of $>90 \%$. The relatively lower yield values of alkyl esters compared to methyl esters could be attributed to difficulty experienced in separation and isolation of alkyl esters and glycerol [28]. In this case the separation of ethyl esters was improved by centrifugation.

\subsection{GC-MS Spectra of Jatropha curcas Ethyl Esters}

The main components of Jatropha curcas ethyl esters are Ethyl hexadecanoate (palmitic acid ethyl ester) (C16:0) Rt 11.21(4), Ethyl octadecanoate (C18:0) Rt 12.302(5) and Ethyl 9(Z)-octadecenoate (C18:1) Rt 12.368(6). Others are ethyldecanoate (C10:0) Rt 6.467(1), ethyl dodecanoate (C11:0) Rt 8.143(2), ethyl nonadecanoate (C19:0) Rt 9.651(3) and ethyl eicosanoate (C22:0) Rt 13.619(7) in smaller quantities (Figure 1).

\subsection{Physicochemical and Fuel Properties of Ethyl Esters from Jatropha curcas 0il}

Jatropha ethyl esters from all the sample sites had physicochemical and fuel properties (Table 6) acceptable by ASTM D 6751 (Table 7). The mean values obtained are comparable with those obtained for Jatropha curcas L. methyl esters from various publications. According to Rajas' findings on analysis of fatty acid methyl ester (FAME) produced from Jatropha curcas the properties obtained were kinematic viscosity $\left(4.82 \mathrm{~mm}^{2} / \mathrm{s}\right)$, flash point $\left(128^{\circ} \mathrm{C}\right)$, specific gravity $(0.84 \mathrm{~g} / \mathrm{ml})$, calorific value $(42.80)$, pour point $\left(-2^{\circ} \mathrm{C}\right)$ and cloud point $8^{\circ} \mathrm{C}$ [29]. Properties of the FAEE biodiesel obtained with bioethanol in this case were comparable to the FAME and ASTM standard biodiesel [30] (Table 7) showing that they were within the specifications.

Data on physicochemical and fuel properties of the biofuel JO FAEE investigated showed that there was no significant difference $(\mathrm{P}<0.05)$ in density, calorific value, kinematic viscosity, pour point and cloud point with those of standard biodiesel samples. Flash point was within the allowable limit of $130^{\circ} \mathrm{C}$ minimum 
Table 5. \%yield of ethyl esters from Jatropha curcas oil from different sites.

\begin{tabular}{|c|c|c|c|c|c|}
\hline Jatropha oil sample & $\begin{array}{c}\text { Volume of } \\
\text { Jatropha oil (ml) }\end{array}$ & $\begin{array}{c}\text { Mass of } \\
\text { Potassium } \\
\text { hydroxide }(\mathrm{g})\end{array}$ & $\begin{array}{l}\text { Volume of dry ethanol } \\
\qquad(\mathrm{ml})\end{array}$ & $\begin{array}{c}\text { Mean } \pm \text { SD } \\
\begin{array}{c}\text { Volume of ethyl esters } \\
(\mathrm{ml})\end{array}\end{array}$ & $\begin{array}{c}\text { Mean } \pm \text { SD \%yield } \\
\text { of ethyl esters }\end{array}$ \\
\hline $\mathrm{JOFA}^{\mathrm{a}}$ & 100 & 3 & 30 & $65 \pm 1.5$ & $65 \pm 1.5$ \\
\hline $\mathrm{JOFB}^{\mathrm{b}}$ & 100 & 3 & 30 & $67 \pm 1.0$ & $67 \pm 1.0$ \\
\hline $\mathrm{JOFC}^{\mathrm{b}}$ & 100 & 3 & 30 & $70 \pm 0.6$ & $70 \pm 0.6$ \\
\hline $\mathrm{JOFD}^{\mathrm{b}}$ & 100 & 3 & 30 & $64 \pm 2.0$ & $64 \pm 2.0$ \\
\hline $\mathrm{JOFE}^{\mathrm{b}}$ & 100 & 3 & 30 & $63 \pm 0.0$ & $63 \pm 0.0$ \\
\hline
\end{tabular}

Table 6. Physicochemical and Fuel Properties of ethyl esters from Jatropha oil.

\begin{tabular}{|c|c|c|c|c|c|c|c|c|c|}
\hline \multirow[b]{2}{*}{$\begin{array}{c}\text { Ethyl ester } \\
\text { (FAEE) } \\
\text { Sample }\end{array}$} & \multirow[b]{2}{*}{$\begin{array}{l}\text { Sampling } \\
\text { farm site }\end{array}$} & \multicolumn{8}{|c|}{ Physicochemical and Fuel Properties (mean values) } \\
\hline & & $\begin{array}{l}\text { Density } \mathrm{kg} / \mathrm{m}^{3} \\
\text { ASTM D4052/ } \\
\text { D1298 at } 20^{\circ} \mathrm{C}\end{array}$ & $\begin{array}{l}\text { Calorific Value } \\
\quad(\mathrm{KJ} / \mathrm{Kg}) \\
\text { ASTM D4809 }\end{array}$ & $\begin{array}{c}\text { Kinematic } \\
\text { Viscosity at } 40^{\circ} \mathrm{C} \\
(\mathrm{cSt}) \\
\text { ASTM D445 }\end{array}$ & $\begin{array}{l}\text { Flash point } \\
\quad\left({ }^{\circ} \mathrm{C}\right) \\
\text { ASTM D93 }\end{array}$ & $\begin{array}{l}\text { Cetane Index } \\
\text { ASTM D4737 }\end{array}$ & $\begin{array}{c}\text { Pour Point } \\
\left({ }^{\circ} \mathrm{C}\right) \text { ASTM } \\
\text { D97 }\end{array}$ & $\begin{array}{c}\text { CFPP } \\
\text { ASTM } \\
\text { D6371 }\end{array}$ & $\begin{array}{l}\text { Cloud Point } \\
\quad\left({ }^{\circ} \mathrm{C}\right) \\
\text { ASTM D2500 }\end{array}$ \\
\hline FAEE1 & SFA & 865.0 & 41.36 & 5.350 & 182 & 63.3 & -10 & -2 & -4 \\
\hline FAEE2 & SFB & 865.9 & 40.84 & 5.405 & 183 & 62.4 & -9 & -2 & -3 \\
\hline FAEE3 & SFC & 868.4 & 40.62 & 5.426 & 183 & 63.2 & -9 & -2 & -4 \\
\hline FAEE4 & SFD & 887.3 & 41.05 & 5.432 & 183 & 63.4 & -8 & -1 & -2 \\
\hline FAEE5 & SFE & 886.2 & 40.56 & 5.430 & 182 & 63.2 & -8 & -2 & -3 \\
\hline
\end{tabular}

Table 7. Biodiesel Specifications and test methods of ASTM D6751-07b.

\begin{tabular}{ccc}
\hline Properties & Limits & Units \\
\hline Flash point & $130 \mathrm{~min}$. & ${ }^{\circ} \mathrm{C}$ \\
Kinematic viscosity at $40^{\circ} \mathrm{C}$ & $1.9-6.0$ & $\mathrm{~mm}^{2} / \mathrm{s}$ \\
Water and sediment & 0.050 max & $\%$ volume \\
Density at $15^{\circ} \mathrm{C}$ & $875-900$ & $\mathrm{~kg} / \mathrm{m}^{3}$ \\
Cloud point & report & ${ }^{\circ} \mathrm{C}$ \\
Pour point & -10 to 12 & ${ }^{\circ} \mathrm{C}$ \\
Acid value & 0.80 max & $\mathrm{mg} \mathrm{KOH} / \mathrm{g}$ \\
Distillation temperature, $90 \%$ recovered & 327 max. & ${ }^{\circ} \mathrm{C}$ \\
\hline
\end{tabular}

despite the $\mathrm{p}>0.05$. This is an advantage making it safe in use. There was a significant difference $(\mathrm{P}>0.05)$ in density, calorific value, kinematic viscosity, pour point and cloud point between JO FAEE and JO samples which justified the need for transesterification. Statistical analyses of data were obtained using scientific data analysis softwares (STATA/SE 13.0 and Xlstat) at $95 \%$ confidence level $(\mathrm{P}<0.05)$ two-tailed.

\section{Conclusion}

Jatropha curcas FAEE produced by transesterification using bioethanol from $R$. 


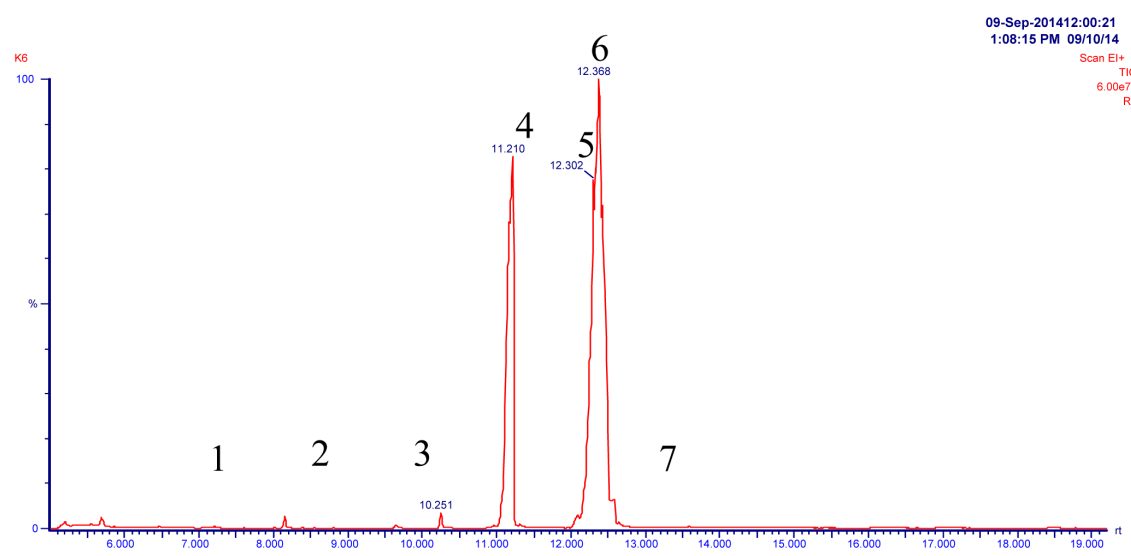

Figure 1. GC-MS spectra of Jatropha curcas ethyl esters.

grande biomass has desirable physicochemical and fuel properties making it a potential quality biofuel. Bioethanol from $R$. grande biomass has a potential to improve sustainability of the renewable energy.

\section{Acknowledgements}

The authors are highly indebted to The National Council of Science and Technology (NACOSTI) for the funding of this study, Mr Kennedy Oketch of SGS KPL laboratotories Mombasa for the work on the physicochemical and fuel properties, Mr David Musyoka and Mr Salim Hassan for their hand in the field during sample collection period, Mr Preston Akenga of JKUAT and Mr George Nzai of Government Chemist Mombasa for the input in GC-MS analysis.

\section{References}

[1] Eviana, H. (2008) A Promising Oil Alternative: Algae Energy. Washington Post. http://www.washingtonpost.com/wp-dyn/content/article/2008/01/03/AR200801030 3907.html

[2] Jumat, S. and Rozaini, A. (2008) Physicochemical Properties of Malaysian Jatropha curcas Seed Oil. Sains Malaysiana, 37, 379-382.

[3] Kumar, A. and Sharma, S. (2008) An Evaluation of Multipurpose Oil Seed Crop for Industrial Uses (Jatropha curcas L.): A Review. Industrial Crops and Products, 28, 1-10. https://doi.org/10.1016/j.indcrop.2008.01.001

[4] Zhou, W., Konar, S.K. and Boocock, D.G.V. (2003) Ethyl Esters from the Single-Phase Base-Catalyzed Ethanolysis of Vegetable Oils. Journal of American Oil Chemists' Society, 80, 367-371. https://doi.org/10.1007/s11746-003-0705-1

[5] Sahoo, P.K. and Das, L.M. (2009) Combustion Analysis of Jatropha, Karanja and Polanga Based Biodiesel as Fuel in a Diesel Engine. Fuel, 88, 994-999. https://doi.org/10.1016/j.fuel.2008.11.012

[6] Svein, J.H. (2009) Seaweed Biofuels: Production of Biogas and Bioethanol from Brown Macroalgae. VDM Verlag, Saarbrucken.

[7] Vicente, G., Martinez, M. and Aracil, J. (2007) Optimisation of Integrated Biodiesel Production. Part I. A Study of the Biodiesel Purity and Yield. Bioresource Technology, 98, 1724-1733. https://doi.org/10.1016/j.biortech.2006.07.024 
[8] Barnwal, B.K. and Sharma, M.P. (2005) Prospects of Biodiesel Production from Vegetable Oils in India. Renewable and Sustainable Energy Reviews, 9, 363-378. https://doi.org/10.1016/j.rser.2004.05.007

[9] Núbia, M.R., Angelo, C.P., Cristina, M.Q., Gisele, O. da R., Leonardo, S.G., Teixeira, L., Guarieiro, L.N., Maria do Carmo, R., Márcia, C.C.V., Michelle, J.C.R., Rosenira, S. da C., Ana, M. de O., Ednildo, A.T., and Jailson, B.A. (2007) The Role of Additives for Diesel and Diesel Blended (Ethanol or Biodiesel) Fuels. A Review Energy Fuels, 21, 2433-2445. https://doi.org/10.1021/ef070060r

[10] Grayburn, W.S., Tatara, R.A., Rosentrater, K.A. and Holbrook, G.P. (2013) Harvesting, Oil Extraction, and Conversion of Local Filamentous Algae Growing in Wastewater into Biodiesel. International Journal of Energy and Environment, 4, 185-190.

[11] Gusakov, A.V., Kondratyeva, E.G. and Sinitsyn, A.P. (2011) Comparison of Two Methods for Assaying Reducing Sugars in the Determination of Carbohydrase Activities. International Journal of Analytical Chemistry, 2011, Article ID: 283658. https://doi.org/10.1155/2011/283658

[12] Harwood, L.M., Moody, C.J. and Percy, J.M. (1999) Experimental Organic Chemistry: Standard and Microscale. 2nd Edition, Wiley-Blackwell Publishing, London.

[13] Han, J., Lian, J., Tian, X., Zhou, S., Zhen, X. and Liu, S. (2014) Total Synthesis of Micromide: A Marine Natural Product. European Journal of Organic Chemistry, 32, 7232-7238. https://doi.org/10.1002/ejoc.201402977

[14] Association of Official Analytical Chemists (2000) Official Methods of Analysis. 17th Edition, The Association of Official Analytical Chemists, Gaithersburg.

[15] Zagonel, G.F., Peralta-Zamora, P. and Ramos, L.P. (2004) Multivariate Monitoring of Soybean oil Ethanolysis by FTIR. Talanta, 63, 1021-1025. https://doi.org/10.1016/j.talanta.2004.01.008

[16] Ejikeme, P.M., Anyaogu, I.D., Ejikeme, C.L., Nwafor, N.P., Egbuonu, C.A.C., Ukogu, K. and Ibemesi, J.A. (2010) Catalysis in Biodiesel Production by Transesterification Processes-An Insight. Journal of Chemistry, 7, 1120-1132.

[17] Gryglewiez, S. (2000) Alkaline-Earth Metal Compounds as Alcoholysis Catalysts for Ester Oils Synthesis. Applied Catalysis A: General, 192, 23-28. https://doi.org/10.1016/S0926-860X(99)00337-3

[18] Fernando, S. and Hanna, M. (2004) Development of a Novel Biofuel Blend Using Ethanol-Biodiesel-Diesel Microemulsions: EB-Diesel. Energy \& Fuels, 18, 1695-1703. https://doi.org/10.1021/ef049865e

[19] Smith, D.C., Forland, S., Bachanos, E., Matejka, M. and Barrett, V. (2001) Qualitative Analysis of Citrus Fruit Extracts by GC/MS. Journal of Chemical Education, 6, 28-31. https://doi.org/10.1007/s00897000450a

[20] Devendra, P.S. and Rakesh, K.T. (2013) Production of Biofuel from Algae: An Economic and Eco-Friendly Resource. International Journal of Science and Research, 2, 352-357.

[21] Fan, X.H. and Burton, R. (2009) Recent Development of Biodiesel Feedstocks and the Applications of Glycerol: A Review. The Open Fuels \& Energy Science Journal, 2, 100-109. https://doi.org/10.2174/1876973X01002010100

[22] Nzikou, J., Matos, L., Mbemba, F., Ndangui, C., Pambou-Tobi, N., Kimbonguila, A., et al. (2009) Characteristics and Composition of Jatropha curcas Oils, Variety Congo-Brazzaville. Research Journal of Applied Sciences, Engineering and Technology, 1, 154-159. 
[23] Pant, K., Khosla, V., Kumar, D. and Gairola, S. (2006) Seed Oil Content Variation in Jatropha curcas Linn. in Different Altitudinal Ranges and Site Conditions in HP India. Lyonia, 11, 31-34.

[24] Ginwal, H., Rawat, P. and Srivastava, R. (2004) Seed Source Variation in Growth Performance and Oil Yield of Jatropha curcas Linn. in Central India. Silvae Genetica, 53, 186-191. https://doi.org/10.1515/sg-2004-0034

[25] Gunstone, F.D. and Harwood, J.L. (2007) Occurrence and Characterization of Oils and Fats. In: Gunstone, F.D., Harwood, J.L. and Dijkstra, A.J., Eds, The Lipid Handbook, 3rd Edition, CRC, Boca Raton, 37-142.

[26] Knothe, G. (2006) Analyzing Biodiesel: Standards and Other Methods. Journal of the American Oil Chemists' Society, 83, 823-833. https://doi.org/10.1007/s11746-006-5033-y

[27] Aminul Islam, A.K.M., Yaakob, Z., Anuar, N., Osman, M. and Primandari, S.R.P. (2015) Preparation of Biodiesel from Jatropha Hybrid Seed Oil through Two-Step Transesterification. Energy Sources, Part A: Recovery, Utilization, and Environmental Effects, 37, 1550-1559.

[28] Anastopoulos, G., Zannikou, Y., Stournas, S. and Kalligeros, S. (2009) Transesterification of Vegetable Oils with Ethanol and Characterization of the Key Fuel Properties of Ethyl Esters. Energies, 2, 362-376. https://doi.org/10.3390/en20200362

[29] Raja, A.S., Robinson, S.D.S. and Robert, L.C. (2011) Biodiesel Production from Jatropha Oil and Its Characterization. Research Journal of Chemical Sciences, 1, 81-85.

[30] ASTM International (2007) ASTM D6751-07b Standard Test Method for Biodiesel. West Conshohocken, PA. 